\title{
The DPP4 inhibitor linagliptin delays the onset of diabetes and preserves $\beta$-cell mass in non-obese diabetic mice
}

\author{
Jacob Jelsing, Niels Vrang, Søren B van Witteloostuijn, Michael Mark ${ }^{1}$ and Thomas Klein ${ }^{1}$ \\ Gubra ApS, Agern Alle 1, 2970 Hørsholm, Denmark \\ ${ }^{1}$ Boehringer Ingelheim Pharma GmbH \& Co. KG, CardioMetabolic Diseases Research, Birkendorfer Strasse 65, D-88397 Biberach, Germany \\ (Correspondence should be addressed to T Klein; Email: thomas_1.klein@boehringer-ingelheim.com)
}

\begin{abstract}
Recent data indicate that dipeptidyl peptidase 4 (DPP4) inhibitors have anti-inflammatory and $\beta$-cell-sparing effects in animal models of type 1 diabetes. To evaluate the effects of the DPP4 inhibitor linagliptin on $\beta$-cell mass and insulinitis, we examined the progression of diabetes (blood glucose $>11 \mathrm{mmol} / \mathrm{l}$ ) in non-obese diabetic (NOD) mice with terminal stereological assessment of cellular pancreatic changes. Female NOD mice were fed a normal chow diet or a diet containing linagliptin $0 \cdot 083 \mathrm{~g} / \mathrm{kg}$ chow for 60 days. At study end, the incidence of diabetes in linagliptin-treated mice was reduced by almost $50 \%$ compared with vehicle (10 of 31 mice
\end{abstract}

vs 18 of 30 mice, $P=0 \cdot 021)$. The total islet mass and total $\beta$-cell mass, identified by insulin immunoreactivity, were greater in non-diabetic linagliptin-treated mice compared with nondiabetic vehicle-treated mice $(P<0 \cdot 01$ for both) but were greatly reduced in diabetic mice irrespective of treatment. No changes were seen in the $\alpha, \delta$ and $\gamma$ endocrine cell pool. Moreover, the total mass of lymphocyte insulinitis was significantly reduced in linagliptin-treated mice compared with vehicle. The data indicate that linagliptin treatment delays the onset of diabetes in NOD mice by protecting $\beta$-cell mass. Journal of Endocrinology (2012) 214, 381-387

\section{Introduction}

The incretin hormone glucagon-like peptide 1 (GLP1) is a gut peptide that is secreted in response to nutrient ingestion. It enhances the glucose-dependent stimulation of insulin secretion and also controls blood glucose (BG) via inhibition of glucagon secretion and gastric emptying (Holst 2007). Long-term treatment with GLP1 receptor agonists reduces food intake and promotes weight loss in both preclinical experiments and clinical studies on patients with or without type 2 diabetes (T2D; Drucker 2006). GLP1 is rapidly degraded in the body by dipeptidyl peptidase 4 (DPP4); thus, inhibition of this enzyme increases GLP1 exposure and thereby its effect on the pancreas (Drucker 2007). For this reason, inhibitors of DPP4 are effective as oral anti-diabetes drugs. Linagliptin, a potent DPP4 inhibitor, is currently approved for the treatment of T2D (Eckhardt et al. 2008, Deacon \& Holst 2010). In rats, as well as in humans, linagliptin exhibits nonlinear pharmacokinetics and shows concentration-dependent plasma protein binding to DPP4 (Fuchs et al. 2009, Heise et al. 2009).

GLP1 is believed to exert its incretin actions through specific GLP1 receptors expressed on pancreatic $\beta$-cells (Holz 2004). Studies of GLP1 analogues and DPP4 inhibitors on $\beta$-cell mass have demonstrated positive effects, either by direct stimulation of $\beta$-cell replication or by inhibition of apoptosis and activation of anti-apoptotic pathways (Xu et al. 1999, Stoffers et al. 2000, Drucker 2003, Cho et al. 2011, Dobrian et al. 2011). Thus, besides their use for the treatment of T2D, GLP1 analogues and DPP4 inhibitors may also possess important cytoprotective and regenerative properties.

As the principal mechanism of action of DPP4 inhibitors is based on the amplification of insulin release via the increase of endogenous GLP1 levels, their use for the treatment of T1D is uncertain given the autoimmune T-cell-dependent eradication of the insulin-producing $\beta$-cells. However, increased GLP1 levels may modify the natural course of $\beta$-cell destruction and/or regeneration, resulting in detectable improvements in insulin secretion and glucose control. Indeed, Kutoh (2011) reported beneficial effects of the DPP4 inhibitor sitagliptin as add-on therapy to insulin in reducing BG levels in a small sample of patients with T1D. In addition, sitagliptin was shown to preserve islet transplants in non-obese diabetic (NOD) mice (Kim et al. 2009, 2010). This mouse model spontaneously develops a form of insulin-dependent diabetes similar to the human disease (Delovitch \& Singh 1997, Anderson \& Bluestone 2005). In this respect, it is worth noting that DPP4 is identical to CD26, a T-cell antigen that plays a role in T-cell-mediated responses (Morimoto \& Schlossman 1998).

The purpose of the current study was to evaluate the effects of the DPP4 inhibitor linagliptin on $\beta$-cell mass and insulinitis during the progression of diabetes in female NOD mice. 


\section{Materials and Methods}

\section{Animals}

A total of 65 female NOD mice ( $8-9$ weeks of age) were obtained from Taconic (Ry, Denmark) and transferred to the Gubra animal stables. On arrival to the animal unit and for the remainder of the study, mice were housed in rodent cages (5-6 per cage) with ad libitum access to food and fresh tap water. The animal room environment was controlled within targeted ranges (temperature, $22 \pm 2{ }^{\circ} \mathrm{C}$; relative humidity, $50 \pm 10 \%$; $12 \mathrm{~h}$ light: $12 \mathrm{~h}$ darkness cycle, lights on from $0600 \mathrm{~h}$ ).

All animal experiments were conducted in accordance with Gubra Bioethical Guidelines, which are fully compliant with internationally accepted principles for the care and use of laboratory animals. The described experiments were covered by personal licenses for J J (2008/561-1565) issued by the Danish Committee for animal research.

\section{In vivo procedures}

Three weeks after arrival, non-fasting BG levels were measured at $0900 \mathrm{~h}$ (Biosen, EKF Diagnostics, Magdeburg, Germany). Animals were then randomised according to $\mathrm{BG}$ and body weight into two groups: a vehicle group $(n=30)$ with ad libitum access to a Sniff Rat-Maintenance diet (Sniff RM, Soest, Germany); or a linagliptin group $(n=31)$ with ad libitum access to a Sniff RM diet including linagliptin $0.083 \mathrm{~g} / \mathrm{kg}$ (equivalent to plasma levels of an oral dose of linagliptin of 3-10 mg/ $\mathrm{kg}$ daily). Four animals were excluded from the study as they had already developed diabetes (BG $>11 \mathrm{mmol} / \mathrm{l})$.

Body weight and mean food intake were measured bi-weekly for the first 3 weeks, then once weekly for the remainder of the study. BG was measured on full blood samples once weekly $(10 \mu \mathrm{l}$ obtained in $\mathrm{LiHe}$-coated capillaries) using a glucose oxidase method (Biosen C-line Clinic, EKF Diagnostics). All samples were taken between 2000 and $2100 \mathrm{~h}$. At experimental day 56, all mice were killed using $\mathrm{CO}_{2}$ anaesthesia followed by decapitation. Terminal blood samples were collected in Na-EDTA tubes containing $1 \mu \mathrm{l}$ DPP4 inhibitor (Millipore (Billerica, MA, USA) catalogue no. DPP4-010, $10 \mu \mathrm{l} / \mathrm{ml}$ blood). Plasma was separated and duplicate samples were analysed for active GLP1 using an active GLP1 ELISA kit (Shibayagi, Gunma, Japan) according to the manufacturer's standard procedures.

\section{Pancreas analyses}

The pancreas was removed 'en bloc' and immersion fixed in $4 \%$ phosphate-buffered formaldehyde. The dissected pancreata were weighed, dehydrated and infiltrated overnight in paraffin using a VIP-100 histokinette (Sakura) and embedded as whole mounts in blocks of paraffin. Each block was trimmed and three series of $5 \mu \mathrm{m}$ sections were sampled using systematic uniform random sampling principles providing sections at seven to ten levels in total. Sections were mounted on slides and subsequently subjected to standard haematoxylin-eosin staining for pathological scoring and double immunohistochemical staining procedures for stereological assessment of $\beta$-cell mass (insulin immunoreactivity) and non$\beta$-cell mass (using an antibody cocktail against pancreatic polypeptide, somatostatin and glucagon). One series was used for double immunohistochemical staining against insulin and the nuclear proliferation marker Ki67, and one series was used to identify and assess CD3 immunoreactivity.

The immunohistochemical staining was performed as follows: after deparaffinisation and microwave oven treatment in citrate buffer ( $\mathrm{pH} \mathrm{6)}$ for $15 \mathrm{~min}$ at $90{ }^{\circ} \mathrm{C}$, sections were stained manually for non- $\beta$-cells using an antibody cocktail consisting of rabbit anti-glucagon (1:1000, H-028-02, Phoenix Pharmaceuticals, Burlingame, CA, USA), rabbit anti-somatostatin (1:1600, A566) and rabbit anti-pancreatic polypeptide (1:1000, B32-1, Euro-Diagnostica, Malmö, Sweden), followed by a biotinylated $\mathrm{F}\left(\mathrm{ab}^{\prime}\right) 2$ fragment antibody (1:2000, 711-066-152, Jackson ImmunoResearch Laboratories, West Grove, PA, USA), HRP complex (1:400, P0397) and development with diaminobenzidine and $\mathrm{NiSO}_{4}$. This was followed by staining $\beta$-cells using a guinea pig anti-insulin (1:100, A0564) combined with HRPcoupled rabbit anti-guinea pig (1:100, P0141) and development with NovaRED (Vector Laboratories, Burlingame, CA, USA). All reagents, including normal sera for blocking, were obtained from DakoCytomation (Copenhagen, Denmark). Double immunohistochemical staining against Ki67 and insulin was performed using a similar approach with the only change being the use of a rat anti-mouse Ki67 antibody (M724, DAKO) diluted 1:400, a secondary nonbiotinylated rabbit anti-rat (AI-4001, Vector Laboratories) diluted 1:200 and amplification for $30 \mathrm{~min}$ using a MACH 2 goat anti-rabbit HRP-Polymer (RHRP520H, Biocare Medical, Concord, CA, USA). CD3 lymphocytes were detected using an anti-CD3 antibody (CMC363, Cell Marque, Rocklin, CA, USA) diluted 1:500.

\section{Stereological estimation of $\beta$-cell mass and lymphocyte insulinitis}

The stereological estimation of $\beta$-cell mass was performed by an observer blinded to the experimental groups. $\beta$-cell mass was estimated by point counting with all points hitting the structure of interest being counted. Sections were scanned in a random systematic way using the newCAST system (Visiopharm, Hørsholm, Denmark) to control the stage and collection of data. A single-point grid per frame was used to estimate pancreas mass and a denser grid (adjusted between animal groups to ensure the accumulation of roughly equal number of 'hits' per sample) was used to estimate $\beta$-cell/ non- $\beta$-cell and lymphocyte mass. Similarly, the grid system was used to correct the presence of non-pancreatic elements in the dissected sample. In principle, the point grid is used to estimate the area fraction of counted cell types. The number of points hitting the structure of interest is then converted into mass by taking the grid ratio into consideration 
(Bock et al. 2003). In general, 100-150 points were counted hitting each structure of interest. The Ki67 proliferation index was calculated using a $2 \mathrm{D}$ counting frame superimposed onto the sections. Ki67-labelled $\beta$-cells and lymphocytes were counted manually and related to the total area. A mean of 130 Ki67-positive $\beta$-cells and 215 proliferating lymphocytes were counted per animal.

\section{Statistical analysis}

Graphical presentations, calculations and statistical analyses were carried out with GraphPad Software (GraphPad Prism version 5.04 for Windows, San Diego, CA, USA; www.graphpad.com). Statistical analysis of cumulative BG, body weight, food intake and water intake levels was performed using a two-way ANOVA with repeated measures. Post hoc analyses were performed in cases with statistical significances $(P<0.05$ considered significant; Newman-Keuls post hoc analysis). Statistical analysis of individual BG data (i.e. non-diabetic vs diabetic proportions) was performed using Fisher's exact test. All pancreatic measurements were performed using one-way ANOVA followed by Tukey's multiple comparison test.

\section{Results}

\section{Development of T1D in the NOD mice}

The progression of diabetes over time is shown in Fig. 1A. After 8 weeks of treatment, the incidence of diabetes (animals with BG $>11 \mathrm{mmol} / \mathrm{l}$ ) in the linagliptin group was reduced by almost $50 \%$ compared with the vehicle group (10 of 31 mice vs 19 of 30 mice developing T1D respectively; $P=0 \cdot 021)$. Mean levels of BG in mice treated with linagliptin were significantly decreased compared with the vehicle group at the end of the study $(14.91 \pm 2.54$ vs $24 \cdot 88 \pm 2.91 \mathrm{mM}$; $P<0 \cdot 05$; Fig. 1B) due to the lower number of diabetic animals. No treatment-related differences were observed in BG levels between the diabetic and non-diabetic subgroups (Fig. 1C). Both water and food intake (measured as mean per cage) tended to increase in the vehicle group towards the end of the study, most likely because of the increased number of diabetic animals in this group (Fig. 1D and E). By contrast, no changes in overall body weight were seen between the linagliptin and vehicle groups $(24 \cdot 12 \pm 0 \cdot 41 \mathrm{vs} 23 \cdot 17 \pm 0 \cdot 54 \mathrm{~g})$. As expected, terminal plasma levels of active GLP1 were significantly increased in the linagliptin group compared with vehicle $(37.49 \pm 4.34$ vs $13.38 \pm 1.97 \mathrm{pg} / \mathrm{ml} ; P<0.01)$. A subgroup analysis of non-diabetic and diabetic mice revealed that diabetic mice treated with linagliptin had highly elevated GLP1 levels at the study end compared with non-diabetic mice treated with linagliptin $(61.29 \pm 8.69$ vs $26.78 \pm 2.54 \mathrm{pg} / \mathrm{ml} ; P<0 \cdot 05$; Fig. 1F). This finding was most likely a direct consequence of increased linagliptin exposure in the diabetic mice due to the increased food intake.

\section{Stereological assessment of $\beta$-cell mass}

No changes were seen in total pancreas mass corrected for non-pancreatic tissue elements (fat and lymph tissue parts) between the linagliptin and vehicle groups
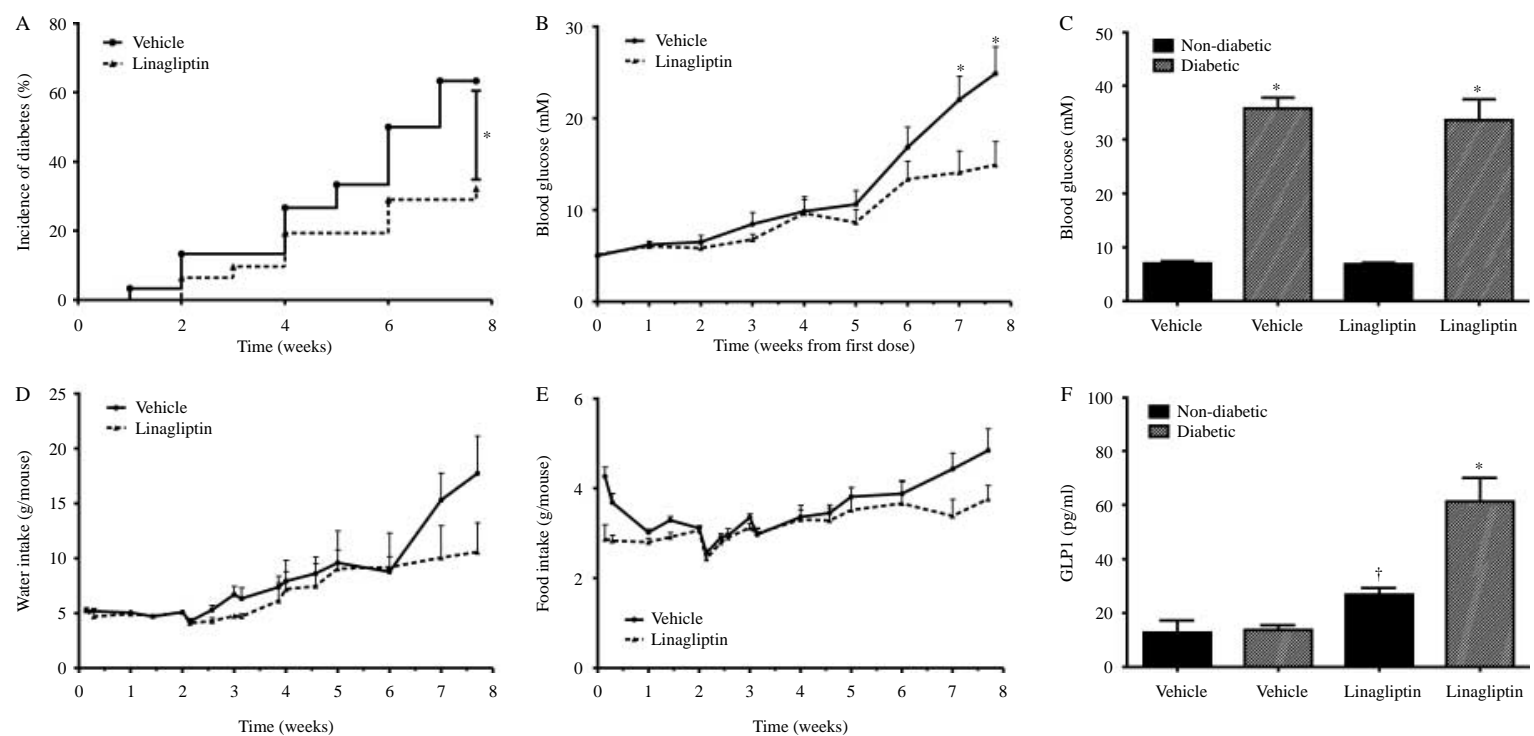

Figure 1 The development of diabetes in NOD mice. The progression of diabetes over time (A; $* P<0 \cdot 05$ vs vehicle), and the effects of linagliptin vs vehicle treatment on mean blood glucose $\left(B ; * P<0 \cdot 05\right.$ vs vehicle), subgroup blood glucose levels $\left(C ;{ }^{*} P<0 \cdot 05\right.$ diabetic vs nondiabetic), water intake (D) and food intake (E) in NOD mice during the 8-week study period. Terminal plasma levels of active GLP1 in NOD mice $\left(\mathrm{F} ;{ }^{*} P<0 \cdot 05\right.$ vs non-diabetic linagliptin-treated mice; ${ }^{\dagger} P<0 \cdot 05$ vs non-diabetic vehicle-treated mice). 
$(277 \cdot 78 \pm 5 \cdot 65$ vs $287 \cdot 24 \pm 10 \cdot 0 \mathrm{mg})$. The quantitative analyses of immunohistochemically stained islet cell types demonstrated a significantly higher $\beta$-cell mass in nondiabetic linagliptin-treated mice compared with non-diabetic vehicle $(0.70 \pm 0.093$ vs $0.35 \pm 0.035 \mathrm{mg})$, with a highly significant reduction in the diabetic groups irrespective of treatment (Fig. 2A). No significant alterations were observed in non- $\beta$-cell mass (Fig. $2 \mathrm{~B}$ ) or unstained endocrine cell mass (Fig. 2C). No changes were observed in Ki67 proliferation index between the non-diabetic linagliptin and vehicle groups (number of proliferating $\beta$-cell profiles per $\beta$-cell area), whereas the index was greatly reduced in diabetic mice (Fig. 2D). The total mass of lymphocyte insulinitis seen in and surrounding the pancreatic islets (Fig. 3) was significantly lower in the non-diabetic linagliptin-treated mice compared with vehicle $(0.89 \pm 0.16$ vs $1.60 \pm 0.19 \mathrm{mg}$; Fig. 4A), as well as in both diabetic groups (Fig. 4A). A similar pattern was observed for proliferating Ki67 immunoreactive lymphocytes (Fig. 4B). Lymphocytes staining positively for CD3 are shown in Fig. 3F.

\section{Discussion}

T1D is a multifactorial autoimmune disease characterised by mononuclear cell infiltration in the pancreatic islets (Castano \& Eisenbarth 1990, Atkinson \& Eisenbarth 2001), leading to an immune response and selective destruction of insulinproducing $\beta$-cells. The NOD mouse spontaneously develops autoimmune diabetes and is regarded as a suitable model of human T1D (Delovitch \& Singh 1997, Anderson \& Bluestone 2005). As in humans, a complex mixture of mononuclear cells infiltrates the islets of NOD mice from 3 weeks of age, leading to the gradual loss of $\beta$-cells (Reddy et al. 2000). In this study, we have demonstrated that the DPP4 inhibitor linagliptin reduced the incidence of diabetes and increased $\beta$-cell mass in female NOD mice, thereby indicating that linagliptin prevents the autoimmune destruction of pancreatic $\beta$-cells.

It still remains unclear whether the effects of DPP4 inhibition on $\beta$-cell sparing are mediated through incretins acting directly on $\beta$-cells or through incretin-independent effects. GLP1 analogues have received much attention for their potential role in restoring $\beta$-cell mass in preclinical models of T2D (Xu et al. 1999, Stoffers et al. 2000, Rolin et al. 2002, Wang \& Brubaker 2002). Among the proposed mechanisms underlying this effect are stimulation of cellular proliferation, inhibition of apoptosis and recovery of residual cellular mass (Hadjiyanni et al. 2008, Shimoda et al. 2011). However, GLP1 is also known to play an immunomodulatory role in rodents, with the GLP1 receptor being expressed in immune cells from the spleen, thymus and lymph nodes of both non-diabetic and diabetic NOD mice (Sherry et al. 2007, Zhang et al. 2007, Hadjiyanni et al. 2008). GLP1 receptor activation has been shown to directly reduce apoptotic cell death after exposure to a diverse number of toxins and cytokines that are likely to contribute to $\beta$-cell destruction (Buteau et al. 2004). In addition, lymphocytes contain significant amounts of membrane-bound DPP4 (Engel et al. 2003), and both splenic DPP4 responsive and lymph node incretin non-responsive T-cell lymphocytes have been shown to infiltrate islets of diabetic NOD mice leading to $\beta$-cell destruction (Kim et al. 2010). Thus, DPP4 inhibition
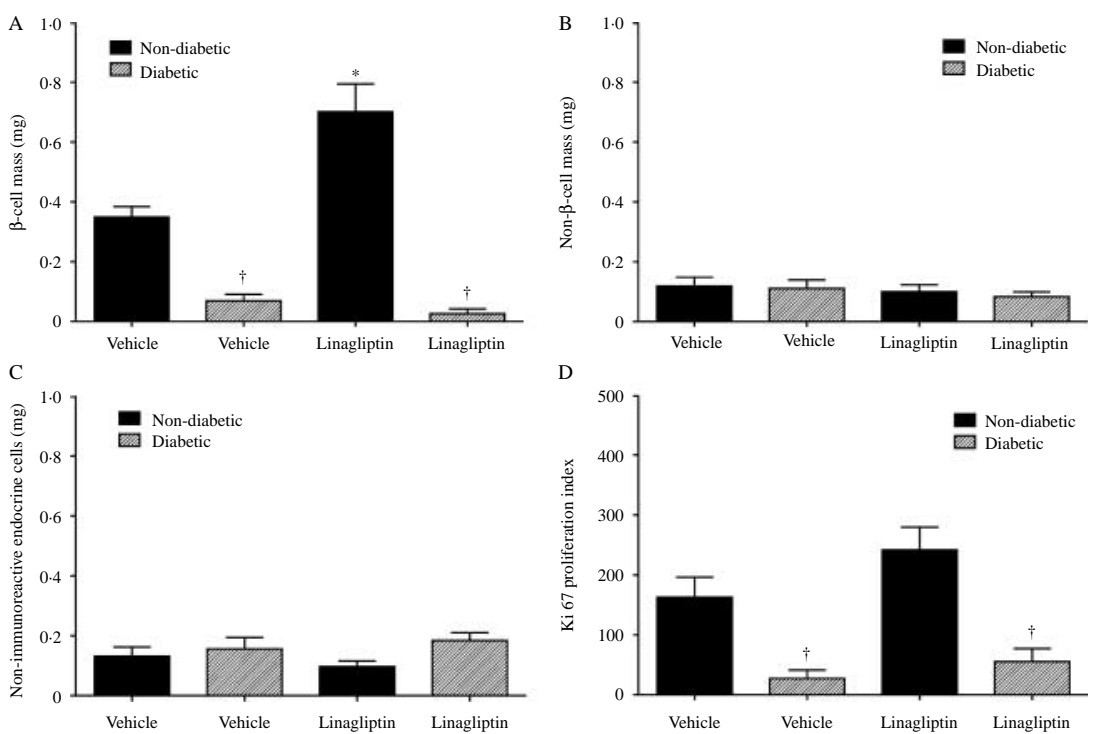

Figure 2 Stereological analyses of NOD mice pancreata. Changes in $\beta$-cell mass (A), non- $\beta$-cell mass (B), non-immunoreactive endocrine cells $(C)$ and Ki67 proliferation index (D) in the linagliptin subgroups compared with vehicle at the end of the 8 -week study period. ${ }^{*} P<0 \cdot 05$ vs non-diabetic vehicle-treated mice; ${ }^{\dagger} P<0.05$ vs non-diabetic mice. 

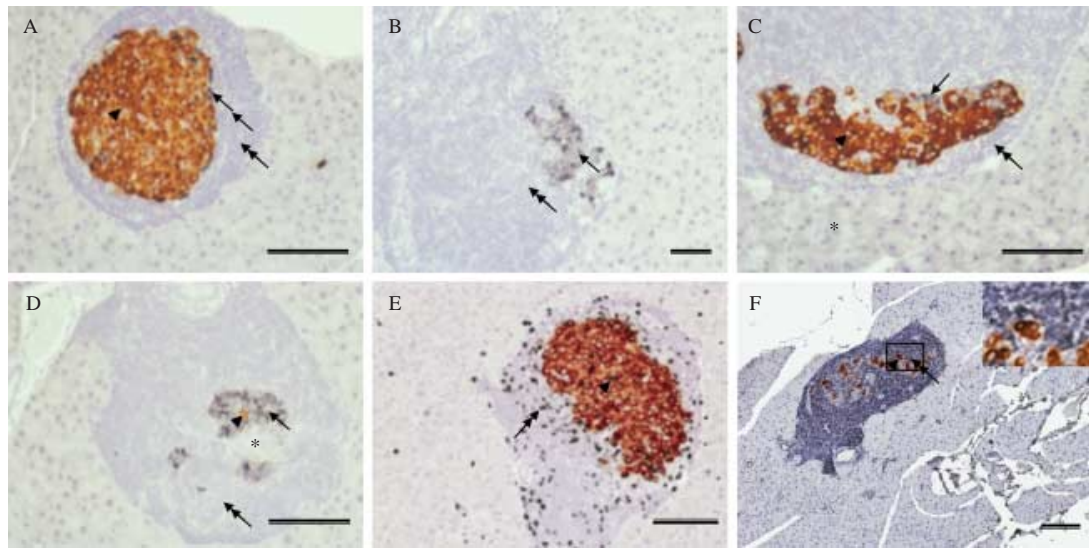

Figure 3 Islet morphology in NOD mice. Immunohistochemical localisation of $\beta$-cells (arrowhead, brown), non- $\beta$-cells (black, arrow) and infiltrating lymphocytes (double arrow) in non-diabetic vehicle (A), diabetic vehicle (B), non-diabetic linagliptin-treated (C) and diabetic linagliptin-treated mice (D). Proliferating Ki67 immunoreactive lymphocytes (double arrow) and $\beta$-cells (arrowhead) are shown in E.

Anti-CD3 immunoreactive lymphocytes (black, double arrow) surrounding $\beta$-cells (brown, arrowhead) are shown in F. Scale bar $=100 \mu \mathrm{m}$. *Non-stained endocrine cells.

may exert anti-inflammatory effects in the pancreatic islets in addition to an insulinotropic effect.

A number of studies have previously indicated a beneficial effect of DPP4 inhibition on $\beta$-cell mass in different animal models of T1D. Kim et al. (2009) demonstrated that sitagliptin was able to reduce the incidence of diabetes in islettransplanted NOD mice coupled with increased $\beta$-cell area and decreased insulinitis (scored as decreased mononuclear cell infiltration). Cho et al. (2011) demonstrated that longterm administration of the novel DPP4 inhibitor DA-1229 increased the mass, replication and neogenesis of $\beta$-cells in streptozotocin-treated mice. In partial agreement with these data, we demonstrate that non-diabetic linagliptin-treated mice have a markedly higher $\beta$-cell mass than their nondiabetic vehicle-treated litter mates. No significant changes were observed in the Ki67 proliferation index of $\beta$-cells, indicating that the higher $\beta$-cell mass is not an incretin effect on $\beta$-cell neogenesis and replication, but rather a $\beta$-cell-sparing effect coupled with improvements in glucose homoeostasis, or a specific anti-inflammatory effect of DPP4 leading to an increased $\beta$-cell survival. This latter interpretation is supported by the decreased mass of infiltrating lymphocytes surrounding the islets in nondiabetic linagliptin-treated mice. Because no changes were observed in non- $\beta$ ( $\alpha, \delta$ and $\gamma$ )-cell mass or in the mass of non-immunoreactive endocrine cells, it appears that the antiinflammatory effects are $\beta$-cell specific. The exact phenotype of the unstained endocrine cells is currently not known. The evaluation of $\beta$-cell-specific MafA and PDX1 antibodies was inconclusive, although it is well known that the expression of both markers is highly susceptible to hyperglycaemia in diabetic conditions (Kaneto et al. 2009). However, as this pool of cells was not significantly altered across the treatment groups, it does not have an overall importance for the presented findings on $\beta$-cell mass. The identification of lymphocytes was based on a histochemical staining protocol that allows for a clear discrimination of infiltrating cells against the exocrine acinar and duct cells, as well as the immunohistochemically detected endocrine cells, in accordance with previously applied protocols (Hadjiyanni et al. 2008, Koulmanda et al. 2008, Kim et al. 2009). Further immunohistochemical analyses demonstrated
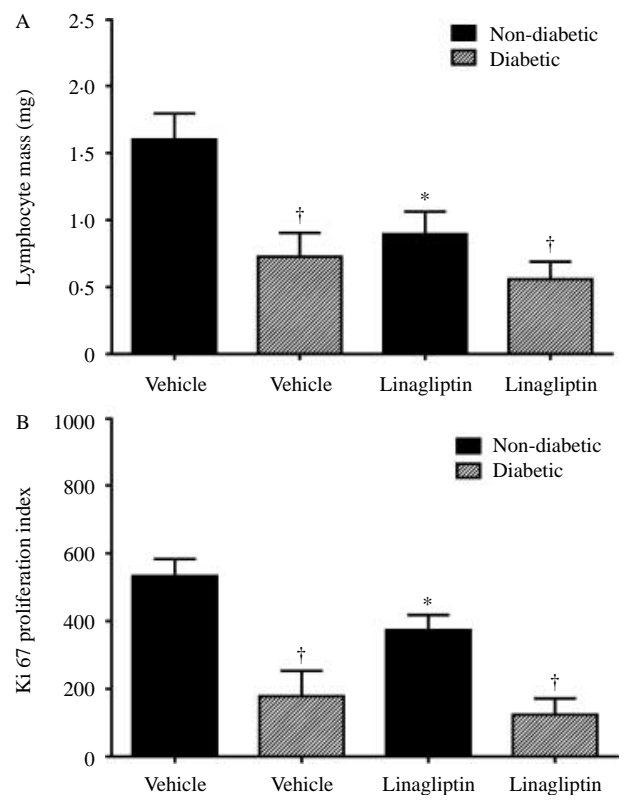

Figure 4 The total mass of lymphocyte insulinitis in non-diabetic and diabetic linagliptin- and vehicle-treated mice. Insulinitis was significantly lower in non-diabetic linagliptin-treated mice compared with vehicle (A). Moreover, the mass of lymphocytes was reduced in all diabetic groups compared with vehicle $(A)$. A similar pattern was observed in the Ki67 proliferation index (B). ${ }^{*} P<0 \cdot 05$ vs non-diabetic vehicle-treated mice; ${ }^{\dagger} P<0 \cdot 05$ vs non-diabetic mice. 
that the infiltrating lymphocytes were mainly CD3-positive T-cells that have previously been considered an important contributor to the development of T1D in NOD mice (Fornari et al. 2011). The mechanism behind the reduced mass of lymphocytes observed in diabetic mice is presently unknown, but it is likely that the inflammatory process will diminish following the onset of diabetes. A similar pattern was observed for $\beta$-cell mass, being markedly reduced in both diabetic groups irrespective of treatment. These data suggest that the onset of diabetes occurs when the mass of $\beta$-cells reaches a critical size.

In conclusion, we demonstrate that the DPP4 inhibitor linagliptin is able to reduce the incidence of diabetes and increase the $\beta$-cell mass in female NOD mice. Moreover, linagliptin is able to reduce lymphocyte insulinitis. The exact mechanism of action of these effects is currently not known, but the pathogenesis of T1D would appear to suggest a mechanism in which linagliptin inhibits the DPP4-mediated stimulation of autoimmune T-cell activation and islet infiltration. Further studies are required to evaluate this hypothesis.

\section{Declaration of interest}

J J, N V and S B v W are employees of Gubra ApS, Denmark. M M and $\mathrm{T} \mathrm{K}$ are full-time employees of Boehringer Ingelheim Pharma $\mathrm{GmbH} \& \mathrm{Co}$. KG, Germany. The authors were fully responsible for all content and editorial decisions, were involved at all stages of manuscript development and have approved the final version.

\section{Funding}

This study was funded by Boehringer Ingelheim. Medical writing assistance, supported financially by Boehringer Ingelheim, was provided by Paul MacCallum of Envision Scientific Solutions during the preparation of this article

\section{References}

Anderson MS \& Bluestone JA 2005 The NOD mouse: a model of immune dysregulation. Annual Review of Immunology 23 447-485. (doi:10.1146/ annurev.immunol.23.021704.115643)

Atkinson MA \& Eisenbarth GS 2001 Type 1 diabetes: new perspectives on disease pathogenesis and treatment. Lancet 358 221-229. (doi:10.1016/ S0140-6736(01)05415-0)

Bock T, Pakkenberg B \& Buschard K 2003 Increased islet volume but unchanged islet number in ob/ob mice. Diabetes 52 1716-1722. (doi:10.2337/diabetes.52.7.1716)

Buteau J, El-Assaad W, Rhodes CJ, Rosenberg L, Joly E \& Prentki M 2004 Glucagon-like peptide-1 prevents beta cell glucolipotoxicity. Diabetologia 47 806-815. (doi:10.1007/s00125-004-1379-6)

Castano L \& Eisenbarth GS 1990 Type-I diabetes: a chronic autoimmune disease of human, mouse, and rat. Annual Review of Immunology 8 647-679. (doi:10.1146/annurev.iy.08.040190.003243)

Cho JM, Jang HW, Cheon H, Jeong YT, Kim DH, Lim YM, Choi SH, Yang EK, Shin CY, Son MH et al. 2011 A novel dipeptidyl peptidase IV inhibitor DA-1229 ameliorates streptozotocin-induced diabetes by increasing $\beta$-cell replication and neogenesis. Diabetes Research and Clinical Practice 91 72-79. (doi:10.1016/j.diabres.2010.10.012)
Deacon CF \& Holst JJ 2010 Linagliptin, a xanthine-based dipeptidyl peptidase-4 inhibitor with an unusual profile for the treatment of type 2 diabetes. Expert Opinion on Investigational Drugs 19 133-140. (doi:10.1517/ 13543780903463862)

Delovitch TL \& Singh B 1997 The nonobese diabetic mouse as a model of autoimmune diabetes: immune dysregulation gets the NOD. Immunity 7 727-738. (doi:10.1016/S1074-7613(00)80392-1)

Dobrian AD, Ma Q, Lindsay JW, Leone KA, Ma K, Coben J, Galkina EV \& Nadler JL 2011 Dipeptidyl peptidase IV inhibitor sitagliptin reduces local inflammation in adipose tissue and in pancreatic islets of obese mice. American Journal of Physiology. Endocrinology and Metabolism 300 E410-E421. (doi:10.1152/ajpendo.00463.2010)

Drucker DJ 2003 Glucagon-like peptide-1 and the islet $\beta$-cell: augmentation of cell proliferation and inhibition of apoptosis. Endocrinology 144 5145-5148. (doi:10.1210/en.2003-1147)

Drucker DJ 2006 The biology of incretin hormones. Cell Metabolism 3 153-165. (doi:10.1016/j.cmet.2006.01.004)

Drucker DJ 2007 Dipeptidyl peptidase-4 inhibition and the treatment of type 2 diabetes: preclinical biology and mechanisms of action. Diabetes Care 30 1335-1343. (doi:10.2337/dc07-0228)

Eckhardt M, Hauel N, Himmelsbach F, Langkopf E, Nar H, Mark M, Tadayyon M, Thomas L, Guth B \& Lotz R 2008 3,5-Dihydroimidazo[4,5-d]pyridazin-4-ones: a class of potent DPP-4 inhibitors. Bioorganic \& Medicinal Chemistry Letters 18 3158-3162. (doi:10.1016/j.bmcl. 2008.04.075)

Engel M, Hoffmann T, Wagner L, Wermann M, Heiser U, Kiefersauer R, Huber R, Bode W, Demuth HU \& Brandstetter H 2003 The crystal structure of dipeptidyl peptidase IV (CD26) reveals its functional regulation and enzymatic mechanism. PNAS 100 5063-5068. (doi:10.1073/pnas. 0230620100)

Fornari TA, Donate PB, Macedo C, Sakamoto-Hojo ET, Donadi EA \& Passos GA 2011 Development of type 1 diabetes mellitus in nonobese diabetic mice follows changes in thymocyte and peripheral T lymphocyte transcriptional activity. Clinical and Developmental Immunology 2011158735. (doi:10.1155/2011/158735)

Fuchs H, Binder R \& Greischel A 2009 Tissue distribution of the novel DPP-4 inhibitor BI 1356 is dominated by saturable binding to its target in rats. Biopharmaceutics \& Drug Disposition 30 229-240. (doi:10.1002/ bdd.662)

Hadjiyanni I, Baggio LL, Poussier P \& Drucker DJ 2008 Exendin-4 modulates diabetes onset in nonobese diabetic mice. Endocrinology 149 1338-1349. (doi:10.1210/en.2007-1137)

Heise T, Graefe-Mody EU, Huttner S, Ring A, Trommeshauser D \& Dugi KA 2009 Pharmacokinetics, pharmacodynamics and tolerability of multiple oral doses of linagliptin, a dipeptidyl peptidase-4 inhibitor in male type 2 diabetes patients. Diabetes, Obesity \& Metabolism 11 786-794. (doi:10.1111/j.1463-1326.2009.01046.x)

Holst JJ 2007 The physiology of glucagon-like peptide 1. Physiological Reviews 87 1409-1439. (doi:10.1152/physrev.00034.2006)

Holz GG 2004 Epac: a new cAMP-binding protein in support of glucagonlike peptide-1 receptor-mediated signal transduction in the pancreatic $\beta$-cell. Diabetes 53 5-13. (doi:10.2337/diabetes.53.1.5)

Kaneto H, Matsuoka TA, Kawashima S, Yamamoto K, Kato K, Miyatsuka T, Katakami N \& Matsuhisa M 2009 Role of MafA in pancreatic $\beta$-cells. Advanced Drug Delivery Reviews 61 489-496. (doi:10.1016/j.addr.2008. 12.015)

Kim SJ, Nian C, Doudet DJ \& McIntosh CH 2009 Dipeptidyl peptidase IV inhibition with MK0431 improves islet graft survival in diabetic NOD mice partially via T-cell modulation. Diabetes 58 641-651. (doi:10.2337/ $\mathrm{db} 08-1101)$

Kim SJ, Nian C \& McIntosh CH 2010 Sitagliptin (MK0431) inhibition of dipeptidyl peptidase IV decreases nonobese diabetic mouse CD4 + T-cell migration through incretin-dependent and -independent pathways. Diabetes 59 1739-1750. (doi:10.2337/db09-1618)

Koulmanda M, Bhasin M, Hoffman L, Fan Z, Qipo A, Shi H, Bonner-Weir S, Putheti P, Degauque N, Libermann TA et al. 2008 Curative and beta cell regenerative effects of alpha1-antitrypsin treatment in autoimmune diabetic NOD mice. PNAS 105 16242-16247. (doi:10.1073/pnas.0808031105) 
Kutoh E 2011 Sitagliptin is effective and safe as add-on to insulin in patients with absolute insulin deficiency: a case series. Journal of Medical Case Reports 5 117. (doi:10.1186/1752-1947-5-117)

Morimoto C \& Schlossman SF 1998 The structure and function of CD26 in the T-cell immune response. Immunological Reviews 161 55-70. (doi:10.1111/j.1600-065X.1998.tb01571.x)

Reddy S, Karanam M, Krissansen G, Nitschke K, Neve J, Poole CA \& Ross JM 2000 Temporal relationship between immune cell influx and the expression of inducible nitric oxide synthase, interleukin-4 and interferongamma in pancreatic islets of NOD mice following adoptive transfer of diabetic spleen cells. Histochemical Journal 32 195-206. (doi:10.1023/ A:1004084232446)

Rolin B, Larsen MO, Gotfredsen CF, Deacon CF, Carr RD, Wilken M \& Knudsen LB 2002 The long-acting GLP-1 derivative NN2211 ameliorates glycemia and increases beta-cell mass in diabetic mice. American Journal of Physiology. Endocrinology and Metabolism 283 E745-E752. (doi:10.1152/ ajpendo.00030.2002)

Sherry NA, Chen W, Kushner JA, Glandt M, Tang Q, Tsai S, Santamaria P, Bluestone JA, Brillantes AM \& Herold KC 2007 Exendin-4 improves reversal of diabetes in NOD mice treated with anti-CD3 monoclonal antibody by enhancing recovery of beta-cells. Endocrinology 148 5136-5144. (doi:10.1210/en.2007-0358)

Shimoda M, Kanda Y, Hamamoto S, Tawaramoto K, Hashiramoto M, Matsuki M \& Kaku K 2011 The human glucagon-like peptide-1 analogue liraglutide preserves pancreatic beta cells via regulation of cell kinetics and suppression of oxidative and endoplasmic reticulum stress in a mouse model of diabetes. Diabetologia 54 1098-1108. (doi:10.1007/s00125-0112069-9)

Stoffers DA, Kieffer TJ, Hussain MA, Drucker DJ, Bonner-Weir S, Habener JF \& Egan JM 2000 Insulinotropic glucagon-like peptide 1 agonists stimulate expression of homeodomain protein IDX-1 and increase islet size in mouse pancreas. Diabetes 49 741-748. (doi:10.2337/diabetes.49.5.741)

Wang Q \& Brubaker PL 2002 Glucagon-like peptide-1 treatment delays the onset of diabetes in 8 week-old db/db mice. Diabetologia 45 1263-1273. (doi:10.1007/s00125-002-0828-3)

Xu G, Stoffers DA, Habener JF \& Bonner-Weir S 1999 Exendin-4 stimulates both beta-cell replication and neogenesis, resulting in increased beta-cell mass and improved glucose tolerance in diabetic rats. Diabetes $\mathbf{4 8}$ 2270-2276. (doi:10.2337/diabetes.48.12.2270)

Zhang J, Tokui Y, Yamagata K, Kozawa J, Sayama K, Iwahashi H, Okita K, Miuchi M, Konya H, Hamaguchi T et al. 2007 Continuous stimulation of human glucagon-like peptide-1 (7-36) amide in a mouse model (NOD) delays onset of autoimmune type 1 diabetes. Diabetologia 50 1900-1909. (doi:10.1007/s00125-007-0737-6)

Received in final form 27 June 2012

Accepted 2 July 2012

Made available online as an Accepted Preprint 2 July 2012 